\title{
John Fryer and the Shanghai Polytechnic: making space for science in nineteenth-century China $†$
}

\author{
DAVID WRIGHT*
}

\section{THE TRANSLATION OF WESTERN SCIENCE INTO LATE IMPERIAL CHINA}

The introduction of modern Western science into late imperial China naturally involved the creation of new linguistic spaces through the translation of science textbooks and the formation of a modern scientific lexicon, ${ }^{1}$ but it also required translation in another, physical, sense through the creation of institutions whereby the new system of practices and ideas could be transmitted. ${ }^{2}$ The Shanghai Polyrechnic, opened in 1876 under the direction of John Fryer, was promoted as an academy for the 'extension of learning': this paper explores the role John Fryer and his Polytechnic played in making space for science in late nineteenth-century China.

t Editor's note. This essay was one of the joint winners in the Society's Singer Prize Competition, 1994.

- 47 Townsend Close, Bracknell, Berkshire RG12 OXE

I would like to thank Dr Elizabeth Frankland Moore, the Sino-British Fellowship Trust, Berkshire County Council, Mr J. M. Hawe, Ms J. Traies and the Governors of Easthampstead Park School, Bracknell, for their support during my research, and Dr C. Cullen, who read a draft of this paper. I will always remember the help and hospitality given during my stay in California by Jane and Christopher Lamb. I am also grateful to Dr F. Dagenais for sharing some of his immense knowledge of the life of John Fryer with me. I gratefully acknowledge the permission of the Bancroft Library, University of California, Berkeley, to quote from the Fryer Papers in their collection.

1 For the general issues in this paper, see Cyrus Peake, 'Some aspects of the introduction of modern science into China', Isis (1934), 22, 173-217; Tsuen-hsuin Tsien, 'Western impact on China through translation', Far Eastern Quarterly (1954), 13, 305-27; John K. Fairbank, The Influence of Modern Western Science and Technology on Japan and China, Rome, 1955; R. G. A. Dolby, 'The transmission of science', History of Science (1977), 15, 1-43; Ssu-yü Teng and John K. Fairbank, China's Response to the West: A Documentary Survey 1839-1923, Cambridge, MA, 1979; Kuo Ting-yee and Liu Kwang-ching, 'Self-strengthening: the pursuit of Western technology', The Cambridge History of China (ed. J. K. Fairbank), 7 vols., Cambridge 1978-96, x (1), 491-542; and James Reardon-Anderson, The Study of Change : Chemistry in China 1840-1949, Cambridge, 1991. On intellectual space for science in late imperial China, see Jonathan Porter, 'The scientific community in early modern China', Isis (1982), 73, 269; David C. Reynolds, 'Redrawing China's intellectual map: images of science in nineteenth-century China', Late Imperial China (1991), 12, 27-61; and Xiong Yuezhi, Xixue Dongjian yu wan Qing shehui [The Eastward movement of Western studies and late Qing Society], Shanghai, 1994, the latter the most comprehensive treatment of the subject yet to appear in Chinese or English.

2 I have based my use of the term 'translation' on Bruno Latour, Science in Action: How to Follow Scientists and Engineers Through Society, Milton Keynes, 1987, 117. I am indebted to Andrew Grout for bringing Latour's work to my attention. 
The Chinese, of course, already had an ancient and sophisticated system of natural philosophy, viewing the world through concepts such as dao (the Way), $q i{ }^{3} l i$ (principle), yin-yang and shu (numerical correspondences), ${ }^{4}$ and there had been a long practical tradition in certain fields such as alchemy, calendrical astronomy and medicine. Yet these older systems of ideas were largely ignored by the Western translators of science textbooks, who created new linguistic spaces using translation methods often strikingly similar to those employed over a millennium earlier by the Central Asian missionaries who had propagated the Buddhist dharma. ${ }^{5}$

Why should the Chinese have shown any interest in being 'enlightened' by the Western sciences? Traditionally the Chinese had regarded themselves as the centre of the world, the teachers, rather than the students, of the 'barbarians'. The researches of Joseph Needham, Nathan Sivin and East Asian historians of Chinese science have indeed shown that in many realms of science and technology China was in advance of Europe until at least AD $1600 .^{6}$

The changed perception of their "explicit interests ${ }^{77}$ came about not as a result of a Kuhnian crisis within the existing Chinese 'science paradigm', 8 but in response to internal and external political forces which by the late 1890 s allowed Western intellectual influences to enter China on an unprecedented scale. ${ }^{9}$

From 1850 onwards the Qing Empire suffered a series of major internal disturbances, the most devastating being the Taiping Rebellion (1851-64), which brought the dynasty to the brink of collapse. Meanwhile, pressed by Western nations to open its doors to trade, following the 'unequal treaties' which concluded the two Opium Wars (1839-42 and 1856-60), China for the first time reluctantly allowed foreign missionaries, businessmen and diplomats access to a number of its cities. Even the territorial integrity of the Chinese Empire was under threat from foreign powers attempting to divide it 'like a melon' into spheres of influence. Yet despite China's evident military weakness and technological backwardness, Western science was not taken seriously until the last decade of the nineteenth century.

The awesome power of the Western guns and steamships - incorporating the insights of the new mathematics, physics and chemistry-and personal observation of their

3 Originally meaning 'vapour' or 'breath', it came to mean something akin to the Stoic pneuma, although in truth there is no Western equivalent.

4 See Joseph Needham et al., Science and Civilisation in China, 6 vols., Cambridge, 1954-96, ii, 216ff.; Ho Peng Yoke, $\mathrm{Li}$, qi and shu: An Introduction to Science and Civilisation in China, Hong Kong, 1985; and Nathan Sivin, Traditional Medicine in Contemporary China, Ann Arbor, 1987, ch. 2 for explanations of the basic concepts of Chinese science.

5 Arthur F. Wright, 'The Chinese language and foreign ideas', in Studies in Chinese Thought (ed. A. F. Wright), Chicago, 1953, 286-303. These techniques included: the use of already-existing terms to 'match the meaning' (a method known as geyi); transliteration, using a restricted group of transcriptor characters; and the creation of some completely novel terms where geyi might mislead the unwary.

6 Needham, op. cit (4), and Sivin, op. cit. (4).

7 Latour, op. cit. (2), 108.

8 As Sivin, op. cit. (4) has pointed out, in traditional China there was no field of study co-extensive with what we should call 'science', so my use of the term 'science paradigm' should be taken to include the main concepts of what we now term 'Chinese science'.

9 The only precedent for such an immense influx of foreign thought was the coming of Buddhism from the first century AD. See E. Zürcher, The Buddhist Conquest of China, Leiden, 1972. 


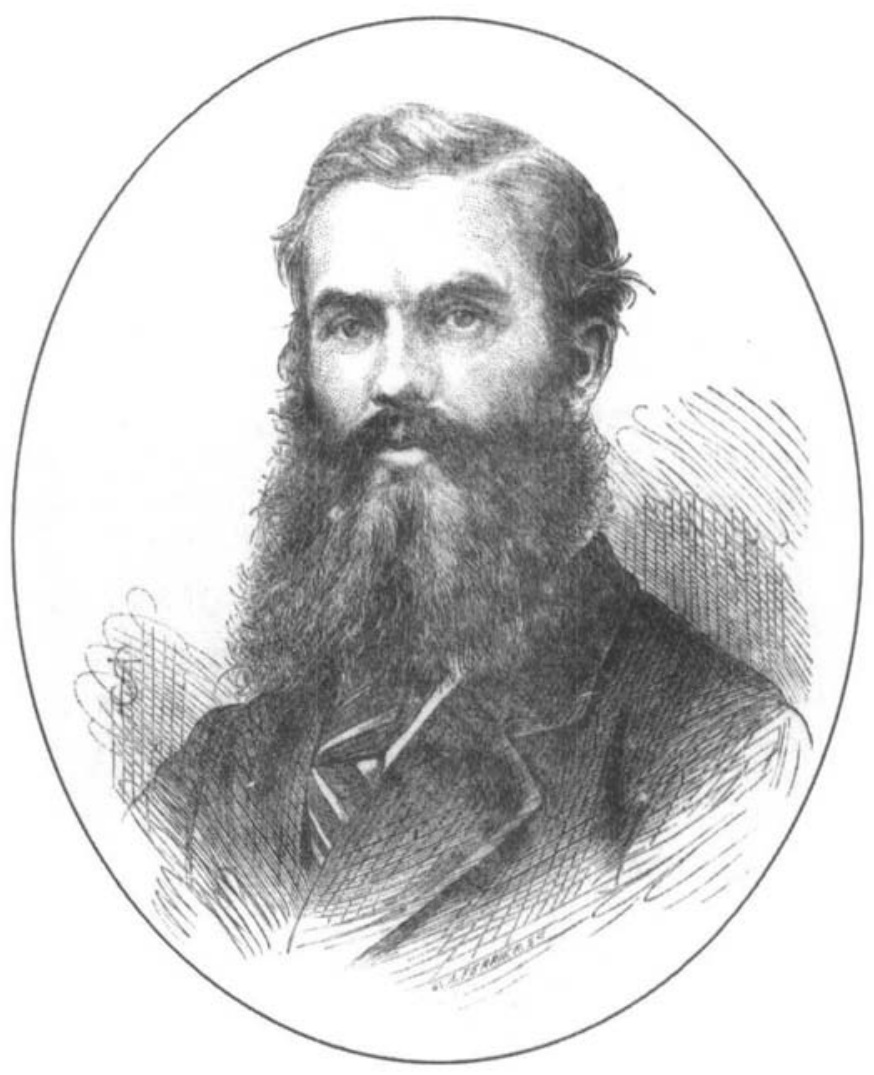

Figure 1. A portrait of John Fryer from Gezhi Huibian 4, 7 (August 1881), 10a. Reproduced by kind permission of the British Library, Oriental and India Office Collections.

effectiveness during the suppression of the Taiping Rebellion catalysed the 'foreign matters movement' (yangwu yundong) after 1860, which set in train the first sustained attempt of the Chinese at 'Self-Strengthening' through the study and imitation of Western technology. The drive for technological innovation was initially centred on the private secretariat of Zeng Guofan (1811-72) based at Anqing in the Lower Yangzi basin, shifting a few years later to the Jiangnan Arsenal in Shanghai, where the basis of the modern Chinese shipbuilding and armament industries was laid.

It was to such a China, torn by rebellions, bruised by a series of foreign defeats and 'unequal treaties', yet reluctantly opening its doors to Western technology and the foreign 'experts' who could reveal its secrets, that John Fryer arrived in 1861 (Figure 1). 


\section{JOHN FRYER'S EARLY YEARS IN CHINA}

In the diary of his first voyage to China, John Fryer wrote

It is with a combination of curious feelings that this journal is commenced. There is a mingled hope and fear, gloom and light; anticipations of a bright future, and occasional forebodings of ill. ${ }^{10}$

His time in China was indeed a mixture of light and gloom, success and bitter disappointment. At the height of his ambition he expected to achieve high office: as he wrote to his brother in 1870 , 'I want to be named among those who are foremost in enlightening and administering the Great Empire';11 and when he left China in 1896 to become the first Louis Agassiz Professor of Oriental Languages in the University of California at Berkeley, he had translated a small library of works on science and technology, and helped to create a chemical nomenclature which is the basis of the modern system.

John Fryer was born in Hythe, Kent on 6 August 1839, into a deeply religious family of modest means. ${ }^{12}$ His father, John Fryer Senior (1812-95) was a businessman and a lay preacher and scripture reader to the coastguard. The family lived in near-poverty, sometimes eased by Mrs Fryer's work as a teacher, and as a boy Fryer himself worked at the local brewery, cleaning boots and knives and running errands.

An unusual feature of his family was the interest they took in China. His father subscribed to a proposed Wesleyan mission ${ }^{13}$ in Guangzhou (Canton), and his mother, Mary Ann Fryer, 'for a time adopted rice as a considerable part of her diet'. ${ }^{14}$ During a visit by a missionary and a Chinese tea merchant from Guangzhou to his home, the latter pressed a silver dollar into the infant John's hand. ${ }^{15}$ At school Fryer always chose to write about China whenever he could, and earned the nickname 'Ching-chongFy-ung' from his classmates. ${ }^{16}$

Having completed his education at Highbury Training College, in 1861 he was offered a post as Head of St Paul's College, a Church of England school in Hong Kong. ${ }^{17}$ Two years later he was invited by the Rev. J. S. Burdon of the Church Missionary Society to join

10 John Fryer, 'Diary of a voyage to China', Fryer Papers: Carton 3, 1. The Fryer Papers (henceforth abbreviated to FP) are held in the Bancroft Library, University of California, Berkeley. See also Fred Dagenais, 'John Fryer's early years in China: I. Diary of his voyage to Hong Kong', in Journal of the Hong Kong Branch of the Royal Asiatic Society (1989), 29, 252-301, and 'John Fryer's early years in China : II. First impressions of Hong Kong and the Chinese people', in ibid. (1990), 30, 146-68.

11 John Fryer to George Fryer, 15 March 1870, FP: Box 1 Folder 1.

12 The Fryers were originally Wesleyans, but Fryer's father split from the Wesleyan Church to set up his own sect, which seems to have been Arminian in character (John Fryer, 'The life of John Fryer Snr. of Hythe, Kent, England', FP: Carton 3, 9). See A. W. Harrison, Arminianism, London, 1937, ch. 8, and David Young, F. D. Maurice and Unitarianism, Oxford, 1992, for accounts of the beliefs of the nineteenth-century Arminians. John Fryer himself worked for the Anglicans in Hong Kong, Beijing and Shanghai, but in a letrer written in 1885 indicated that by the late 1870s he had become a follower of Unitarianism, FP: Box 1 Folder 6 .

13 Fryer, 'Life of John Fryer Snr.', FP: Carton 3, 15.

14 John Fryer, 'Reminiscences of life in China', FP: Carton 3, 2.

15 Fryer, 'Reminiscences', FP: Carton 3, 3.

16 Fryer, 'Reminiscences', FP: Carton 3, 3.

17 Fryer, 'Reminiscences', FP: Carton 3, 3. 
the Tongwenguan (Interpreters' College, also translated as 'School of Combined Learning') in Beijing, which had opened only a year earlier. Here he perfected his command of Mandarin Chinese, and by 1864 he had become an agent of the Church Missionary Society, ${ }^{18}$ which agreed to help him arrange for his fiancée Anna Roleston (1838-79) to come to China, and the following year he married her in Beijing. ${ }^{19}$ Fryer claimed later that he left the Beijing Tongwenguan owing to his 'dislike of teaching English' and the 'interference of petty officials', but his departure was more likely owing to the scandal surrounding his wife's voyage to China ${ }^{20}$ Anna had to return to Britain ${ }^{21}$ whilst Fryer's restless journey across China resumed in 1865, when he went, with considerable reluctance, ${ }^{22}$ to Shanghai to set up a small Anglo-Chinese School in a rather out-of-the-way part of the city. ${ }^{23} \mathrm{He}$ found teaching burdensome and unrewarding, and his frustration and loneliness ${ }^{24}$ were alleviated only by his work as editor of the Shanghai Xinbao (Shanghai Gazette) from 1866 to $1868 .{ }^{25}$

It would seem that his interest in the possibilities of science began here, at the AngloChinese School in Shanghai. He wrote to his brother George

By next mail will you please send me about as much magnesium wire as you can conveniently do in a letter, just for showing experiments to the Chinese. If you can get me a catalogue of scientific instruments and prices I should be glad to have it by next mail also. Such instruments as microscopes, telescopes, magic lantern slides, electric machines and galvanic batteries, air pump and such philosophical apparatus. Also a small packet of those cards for children which by application of a damped paper produce a photograph (if not very clear). ${ }^{26}$

There is no clue as to the occasion of such an apparently sudden and specific interest in experimental science. It seems unlikely that Fryer wanted the equipment for his AngloChinese School, and suggests that he was already beginning to realize the interest some of the Chinese mandarins had in science, and was arranging a display for them. This might also explain why he was chosen, over other possible candidates, for the post of chief translator, his linguistic skills having been already proven as editor of the Shanghai Xinbao.

18 John Fryer, 'Recollections of life in Peking', FP: Carton 3, and Journal of the North China Branch of the Royal Asiatic Society (1929), 60, p. ii.

19 John Fryer, 'Sketch of the life of Mrs Anna Roleston Fryer', FP: Carton 1, 1.

20 John Fryer to Rev. H. Venn, 4 July 1865, Church Missionary Society Archives (CMS), University of Birmingham Library, $\mathrm{C} \mathrm{CH} / 038 / 4$. Anna was supposed to have been seduced by the captain of the ship, "under the influence of a drug of strong aphrodisiacal properties'.

21 Fryer, 'Life of Mrs Fryer', FP: Carron 3, 5.

22 John Fryer to Rev. H. Venn, 28 February 1865, CMS Archives, C CH/038/3.

23 One of his most famous students was the comprador and advocate of reform Zheng Guanying (1842-1923).

24 One touching letter to Anna survives, written in verse: 'Oh could you but know what I undergo day after day in this place far away living alone unloved and unknown spending my live [life] in an unequal strife standing my ground till things shall work round...', 8 November 1867, FP: Box 1 Folder 6.

25 Shanghai Xinbao (1854-72), the Chinese edition of the North China Herald, was edited successively by Marquis L. Wood, John Fryer and Young J. Allen. See Roswell S. Britton, The Chinese Periodical Press 1800-1912, Shanghai, 1933, 49.

26 John Fryer to George Fryer, 25 March 1867, FP: Box 1 Folder 1. 


\section{SCIENCE TRANSLATION: 'A DULL AND UNTHANKFUL TASK'}

Around the time Fryer was teaching in Shanghai, Zeng Guofan was considering setting up a translation bureau ${ }^{27}$ to produce the technical books which the Jiangnan Arsenal would need if they were successfully to imitate Western techniques, and it was here that John Fryer found his life's chief work. He joined the Department for the Translation of Foreign Books at the Jiangnan Arsenal in mid-1868, occupying a position sufficiently well paid that Anna was at last able to rejoin him. He was approached, probably earlier the same year, whilst he was still Head of the Anglo-Chinese School, to begin translating scientific books for the Arsenal, the first being a book on practical geometry which Fryer translated at his home, ${ }^{28}$ and by June of the same year he was already working in a building set apart for the purpose of translation.

It is a great relief to feel settled and able to get on quietly with one's work. Indeed I may say I was never more happy in my life than I am in my new situation of Translator of Scientific Books for the Chinese Government. It is an honourable and useful position as well as being respectable, and with a salary of $£ 800$ a year or thereabouts I can afford to live well. ${ }^{29}$

He was also keenly aware of his lack of knowledge of science, but he set to work to teach himself what he would need.

I have always loved science but have never had the time or opportunity to cultivate it. Now it is my duty and a very pleasant duty it is too. I go at it in real earnest and although I shall never make a scientific man I yet aspire to becoming familiar with several of its branches. I have begun by studying and translating three subjects at once. In the morning I take coal and coal-mining in all its details, in the afternoon I dig into chemistry and in the evening acoustics. ${ }^{30}$

His initial impressions of his Chinese colleagues at the Arsenal were very positive, and he spoke in the same letter of his growing friendship with Xu Jianyin (1845-1901):

One young fellow who is a mandarin of the rank of district magistrate and wears a white button and flowered peacock's feather has become like a brother to me. We work very much together and he often comes to my house and dines. His name is Hsü-chung-hu [Xu Zhonghu $=\mathrm{Xu}$ Jianyin]... Perhaps I may be able to bring him to England when I return. ${ }^{31}$

And in another letter he compared the Chinese favourably with his Western acquaintances:

The Chinese mandarins are very good people and have treated me with far more kindness and fairness than the Europeans I have been connected with in China. They are slow in making friends and in making promises, but when once a promise is made, they always seem to adhere to it. ${ }^{32}$

Money was a constant theme in his early letters home, his salary of about $£ 800$ per year being a considerable sum for the time. His subordinate translator Daniel Jerome Macgowan (1814-93), a medical missionary, earned only two-thirds of his salary, ${ }^{33}$ and when Carl Kreyer arrived in 1869 as another subordinate, he exulted to his brother 'I am

27 Ssu-yü Teng and J. K. Fairbank, op. cit. (1), 64-5.

28 John Fryer to Broadhurst Tootal, 28 April 1868, FP: Box 1 Folder 2.

29 John Fryer to Cousin Susy (no surname identified), 11 July 1868, FP: Box 1 Folder 3.

30 FP: Box 1 Folder 3.

31 For Xu Jianyin, see David Wright, 'Careers in Western science in nineteenth-century China: Xu Shou and Xu Jianyin', Journal of the Royal Asiatic Society (1995), 5, 49-90.

32 John Fryer to Uncle and Aunt, 1 November 1869, FP: Box 1 Folder 4.

33 John Fryer to Cousin Susy, 11 July 1868, FP: Box 1 Folder 3, 2. 
almost "cock of the walk", '34 Fryer, a 'half-educated man', ${ }^{35}$ could supervise men who were academically far better qualified than himself, yet he recognized that they might one day outstrip him, and deprive him of his ambition.

At present my position is merely a day of 'small and feeble things'. I have a long way yet to climb, but 1 have a start of most of my competitors. One of those who are associated with me is Dr. [Daniel Jerome] Macgowan who has been in China nearly three times as long as 1 have ${ }^{36}$ and the other is a missionary who has been in China more than double the time I have. At present I am before them in position and salary, and it shall be a hard struggle if I cannot keep ahead of them.

His foreign competitors rarely stayed long in post, but it was his relations with his Chinese collaborators which were to prove the most problematic, as the whole enterprise of the translation of Western science - in both senses - depended upon their collaboration.

\section{FRYER AND HIS CHINESE COLLABORATORS}

Fryer worked with some of the ablest Chinese scholars of his day, including the mathematicians Li Shanlan (1811-82) and Hua Hengfang (1833-1902), the natural scientist $\mathrm{Xu}$ Shou (1818-84) and his son Xu Jianyin. These men came from the rradition of kaozheng (evidential research) scholarship, ${ }^{37}$ and the last three had been engaged in their own scientific studies in the Wuxi area of the Yangzi Valley even before the first translated Western science texts began to appear in the 1850 s. Stimulated by the new world of experiments revealed by works such as Bowu xinbian (A new account of natural philosophy), ${ }^{38}$ they energetically developed a small scientific community only to see it swept away by the Taiping Rebellion.

From 1861 they went to work in the $m u f u$ (private secretariat) of Zeng Guofan, first in shipbuilding at Anqing and then moving to the Jiangnan Arsenal in Shanghai, where they carried out a series of important translations with John Fryer and other foreigners in the service of the Chinese Government.

The formidable linguistic problems involved in translating Western terms into intelligible Chinese were believed by some to be insurmountable. Chinese, it was claimed, was too 'vague' to be able to carry the precise terminology of science, but Fryer and his Chinese collaborators proved this view mistaken, developing in the process a chemical nomenclature which forms the core of the modern system. ${ }^{39}$ Nevertheless, Fryer wrote

34 John Fryer to George Fryer, 7 December 1869, FP: Box 1 Folder 4.

35 John Fryer to Uncle and Aunt, 1 November 1869, FP: Box 1 Folder 4.

36 Daniel Jerome Macgowan (1814-93) arrived in China in 1843.

37 See Benjamin Elman, From Philosophy to Philology: Intellectual and Social Aspects of Change in Late Imperial China, Cambridge, MA, 1984.

38 Published in 1855 by the medical missionary Benjamin Hobson (1816-73).

39 John Fryer, 'Scientific terminology: present discrepancies and the means of securing uniformity', Records of the General Conference of the Protestant Missionaries of China Held at Shanghai, May 7-20, 1890, Shanghai, 1890, 531-49. The books translated at the Jiangnan Arsenal mainly related to military technology, but also included works on the fundamental sciences such as optics, chemistry and electricity. See the appendix to A. A. Bennetr, John Fryer: The Introduction of Western Science and Technology in Nineteenth-Century China, Cambridge, MA, 1967. Fryer's translations include works on chemistry, physics, navigation, etc. 
The work of translating and compiling scientific books is for the time being perhaps about as dull and unthankful a task as any foreigner could engage in especially in such a secluded place as the Kiangnan [Jiangnan] Arsenal, and under the depressing influences of the climate of this part of China. Nothing but a strong sense of duty and a firm belief that this kind of labour is one of the most effective means, under the Divine Guidance, for bringing about the intellectual and moral regeneration of this great country, has sufficed to render endurable the long and weary years of close and continuous application which it has involved. ${ }^{40}$

Fryer sought new outlets for his energy: as a former editor, journalism was an obvious field for his activities, reporting the good news of modern Western science to the Celestial Empire.

\section{A WALLED ACADEMY: 'EMPTY HALLS AND INCIPIENT DECAY'}

The translation of Western science, in the non-linguistic sense of its 'transplantation', took place through a small handful of institutions, mainly in coastal cities, during the late Qing period. Modern government schools such as the Beijing Tongwenguan ${ }^{41}$ included natural science in their curriculum, but the results were meagre, few of the students going on to further study or to take posts in which their knowledge of science had any direct value.

The founding of the Shanghai Polytechnic Institution and Reading Rooms arose out of a proposal in 1874 by Walter Medhurst, the British consul in Shanghai, that a public reading room be established, the aim being 'to extend the knowledge of the Chinese in regard to Foreign countries and topics generally, and thereby to promote good feeling between foreigners and Chinese'. ${ }^{22}$ The name Medhurst proposed for the reading room was Gezhi Shuyuan (Academy for the Extension of Learning). Gezhi happened also to be the word then current for 'science', and from the outset Western science was to be its central theme. Article 9 of Medhurst's prospectus stated that

The rooms [are] to be supplied with maps, philosophical [that is, scientific] instruments of various kinds, and any models of steam engines, locomotives, telegraphic apparatus \& c., that can be procured. ${ }^{43}$

whilst Article 12 declared that

Lectures on scientific subjects of practical value or general topics [are] to be delivered in the Chinese language, now and then, as the Committee may arrange. ${ }^{44}$

The idea of an academy was not at all new to China. The shuyuan had existed for centuries before Westerners arrived, often situated in remote rural areas, and directed by

40 John Fryer, 'Science in China', Nature (1881), 24, 56.

41 Knight Biggerstaff, 'The T'ung Wen Kuan', The Chinese Social and Political Science Review (1934), 18, $307-40$.

42 Walter Medhurst, North China Daily News, 5 March 1874, cited in John Fryer, First Report of the Shanghai Polytechnic Institution and Reading Rooms, Shanghai, 1875, 4. Other accounts of the Shanghai Polytechnic may be found in Knight Biggerstaff, 'Shanghai Polytechnic Institution and Reading Room : an attempt to introduce Western science and rechnology to the Chinese', Pacific Historical Review (1956), 250, 127-49 and Wang Ermin, Shanghai Gezhi Shuyuan zhilie [An account of the Shanghai Polytechnic], Hong Kong, 1980.

43 Fryer, op. cit. (42), 4.

44 Fryer, op. cit. (42), 4. 


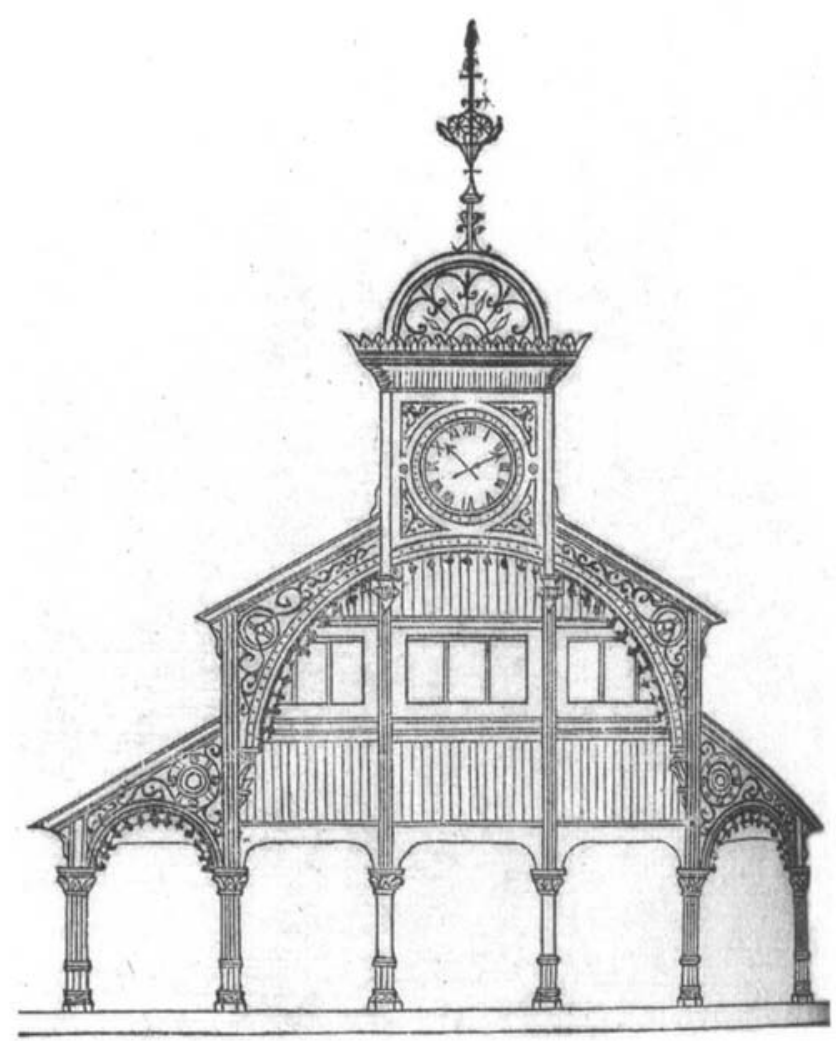

Figure 2. The 'Crystal Palace', design for the Polytechnic building, from Gezhi Huibian (1877), 2, 7a. Reproduced by kind permission of the British Library, Oriental and India Office Collections.

a famous scholar, the so-called 'mountain-elder' or shanzhang. ${ }^{45}$ The novelty of the Gezhi Shuyuan lay in the concept of a shuyuan teaching Western science.

The first Management Committee included Medhurst himself, John Fryer, and his translating associate the missionary-scholar Alexander Wylie (1815-87), and by 1875 it had expanded to include Xu Shou and Xu Jianyin. Its English name was soon changed to 'The Chinese Polytechnic Institution and Reading Rooms', and its aims were now formally expressed as bringing 'the Sciences, Arts, and Manufactures of the Western Nations in the most practical manner possible before the Chinese'. ${ }^{46}$

The Polytechnic Institution building opened in 1876, after some unfortunate publicity which raised expectations far beyond what could be delivered, with talk of a 'Crystal Palace' of iron and glass (see Figure 2). ${ }^{47}$ The only public event of the first year was a talk

45 See Suzanne Barnett, 'Foochow's academies: public ordering and expanding education in the late nineteenth century', Bulletin of the Institute of Modern History, Taibei (1987), 16, 513-87 and Chen Yuanhui et al., Zhongguo gudai de shuyuan zhidu [The ancient Chinese academy system], Shanghai, 1981. For an interesting account of the traditional shuyuan see Barry C. Keenan, Imperial China's Last Academies: Social Change in the Lower Yangzi 1864-1911, Berkeley, 1994.

46 Fryer, op. cit. (42), 5.

47 Fryer, op. cit. (42), 9, and Gezhi Huibian (1877), 2, 6b-7b. 
on electricity by the missionary educator Calvin Mateer $(1836-1908)^{48}$ in June 1877 to an audience of fifty to sixty people. ${ }^{49}$ In his Second Report, Fryer stated how hard it was to find foreigners who could lecture in Chinese, and, less plausibly, that the great variety of dialects in Shanghai made it hard for the audience to follow what was being said. ${ }^{50}$ A major disappointment was the poor response of Western manufacturers to a request to send samples of their wares to display, out of fear that they would be copied by Chinese artisans. $^{51}$

Fryer had to admit there had been 'but little progress': the Reading Rooms attracted few visitors, and the library consisted of only a few hundred volumes. ${ }^{52}$ (Xu Shou seems to have been working mainly on fund-raising and the purchase of land.) By 1877 the failure became public knowledge when criticism by the progenitor of the Institution appeared in the North China Herald:

Mr Medhurst drew a contrast between the Museum at Hongkong and the Polytechnic at Shanghai. The former, he tells us in a letter read at the last meeting of the Shanghai Polytechnic, is crowded with Chinese visitors who take an intelligent interest in the specimens exhibited; the latter is practically deserted, or honoured at odd intervals by the visit of some passing stranger who, hearing of its high-sounding name, has turned his steps thitherward to find empty halls and incipient decay which seem to be the fate of all Chinese undertakings from their very commencement ... we ... find H. E. Li Hung-chang [Hongzhang] appointing officials in connexion with the affairs of the institution - in other words that it is being made part of that curious net within which the Viceroy of Chihli $[\mathrm{Zhili}]^{53}$ is striving to enfold every interest in the Empire. To monopolise the carrying trade of the Empire at the expense of the trade pretended to be fostered, and to steadily repress all private enterprise in any form likely to confer a tangible good upon the country are not sufficient for the aims of the present party in power. Beyond these, it strives to attain to the same pre-eminence in matters intellectual, and steadily to put down any attempt at freedom of thought as of freedom of trade or loco-motion. The manner in which it deals with the Press is one instance of this, and we may add the Polytechnic is another. ${ }^{54}$

This diatribe illustrates the unexpectedly political character of an apparently innocuous educational institution. The supercilious attitude displayed towards any Chinese-run enterprise was reinforced by the unfavourable comparison with its colonial counterpart in Hong Kong. That the Polytechnic might be part of the viceroy Li Hongzhang's regional power-base was a suspicion given more credence by the fact that the Chinese members of the committee - and Fryer himself - were all close associates of $\mathrm{Li}$, who had retained effective control of the Jiangnan Arsenal even though his power-base now lay far to the north. Foreign businessmen apparently felt that the Chinese Government was using the Polytechnic as means to control them : far from welcoming it as a showcase for their goods, they saw it as a Chinese ploy to pirate their designs and imitate their manufactures.

To the Chinese, also, the Polytechnic had little to offer : a few hundred books on obscure,

48 Rev. C. W. Mateer ran Dengzhou College in Shandong Province, which provided the most extensive science curriculum of any missionary school in China.

49 John Fryer, Second Report of the Chinese Polytechnic and Reading Rooms, Shanghai, 1878, 7.

50 Fryer, op. cit. (49), 7.

51 Fryer, op. cit. (49), 8.

52 Fryer, op. cit. (49), 7.

53 Zhili was the province surrounding the capital. Li Hongzhang (1823-1901), the leading Chinese statesman of the late nineteenth century, was involved in most of the self-strengthening projects from the early $1860 \mathrm{~s}$ onwards.

54 Nortb China Herald, 15 March 1877, 261. 
foreign, subjects, together with rather unexciting displays, including a globe, a hightemperature electrical thermometer, needles, fish-hooks, buttons, and a large map indicating suitable routes for railway lines in China. ${ }^{55}$

By the time of his 'Third Report' in $1883,{ }^{56}$ Fryer had to admit that beyond the raising of more money (mainly by Xu Shou) and the assembly of a large collection of chemical and electrical apparatus, nothing of note had been achieved, although the 'empty halls' were beginning to attract more visitors. Hua Hengfang had become Curator, and according to Fryer 'the doors [were] open day and night throughout the year, and all respectable natives [were] admitted'. ${ }^{57}$ There were now as many as one hundred visitors per month: those who had come some distance were offered accommodation. Hua's colleague Xu Shou, who had become Treasurer, now lived on the premises for days at a time, entertained visitors and gave 'special explanations to his particular friends when desired' as well as carrying out chemical analyses of metal ores, and selling scientific apparatus. ${ }^{58}$

The permanent exhibition of goods and manufactures which had been planned was finally abandoned owing to lack of interest from foreign manufacturers, and the London committee which Fryer had set up to oversee the project was dissolved. ${ }^{59}$

In the 'Third Report' Fryer also argued, by now in some desperation, that classes and lectures should begin, proposing topics such as mining, metallurgy and chemistry, but funds were not forthcoming and this idea, too, died a natural death.

Xu Shou himself died in 1884, and Fryer's 'Fourth Report' revealed the situation as even bleaker than had been apparent before. The original 'public and educational character of the Institution' had been almost entirely lost. Relations between the Management Committee and Xu Shou, who (along with various family members) had taken up residence there, had sunk to their lowest ebb, for, as Fryer put it, 'Finding the wishes of the Committee did not accord with his own, [Xu Shou] step by step ignored them altogether. ${ }^{160}$ Books lay unused on the shelves, apparatus rotted in glass cases, windows were never cleaned and the front door was more often than not closed to visitors. Fryer himself found it difficult to gain access to the building at times. The Institution had become 'dead to the outer world '. ${ }^{61}$ Even after Xu Shou's death, his son Xu Jianyin attempted to keep control of the place, having a "wall with an iron gate and railings ${ }^{72}$ built around the building, which had by now come to serve more as a private residence for the Xu family, and a

55 Gezhi Huibian (1876), 1, 11b-12a. Yet more impressive machinery would not have impressed the envoy Liu Xihong who visited the Polytechnic on his way to Britain, and wrote that, with its distasteful emphasis on the practical, it ought to be called a 'Hall of the Arts' [yi lin zhi tang] rather than an 'Academy for the Extension of Knowledge'. Liu Xihong, 'Yingyao siji' [Private notes on a journey to Britain], in Zou xiang shijie congshu [The Going Our into the World Collection] (ed. Zhong Shuhe), Changsha, 1986, 50-1.

56 John Fryer, 'Third report on the Chinese Polytechnic Institution and Reading Rooms', North China Herald, 18 April $1883,432-4$.

57 Fryer, op. cit. $(56), 433$.

58 Fryer, op. cit. (56), 433.

59 Fryer, op. cit. (56), 433.

60 John Fryer, 'Fourth report of the Chinese Polytechnic Institution and Reading Rooms', North China Herald, 10 July $1885,44-5$, on 44.

61 Fryer, op. cit. $(60), 44$.

62 Fryer, op. cit. $(60), 44$. 
warehouse for decaying scientific equipment, than a place for public enlightenment. Foreign interest had dwindled to almost nothing, and few Chinese people even seemed aware of its existence. ${ }^{63}$

For Fryer, the failure of the Polytechnic as a space for public science was a bitter disappointment, and came at a time when his work as a translator had also come to hold little pleasure for him. He began to contemplate throwing it all up for the sake of a Unitarian mission to the Chinese, ${ }^{64}$ yet in the end the other, more successful, popularization ventures associated with the Polytechnic seem to have restrained him from complete renunciation of his original aim of encouraging 'public science' in China; progress was desperately slow, but the Polytechnic would eventually have its day.

\section{OTHER SCIENCE POPULARIZATION ACTIVITIES OF THE POLYTECHNIC}

Frustrated by these failures, Fryer turned to other means of communicating science to the Chinese. The most successful was the journal Gezhi Huibian (The Chinese Scientific Magazine, later The Chinese Scientific and Industrial Magazine), which he had founded, and which he published himself (although nominally it remained associated with the Polytechnic) between 1876 and 1892. The magazine contained a huge range of articles on matters of scientific and technological interest, including areas such as biology and anthropology which his Chinese Government work did not allow him to translate. It also included a Readers' Queries section which throws a fascinating light on the interests of the Chinese readership. ${ }^{65}$

In 1884 Fryer set up the Gezhi Shushi (Chinese Scientific Book Depot), which was an outlet not only for the official translations from the Jiangnan Arsenal, but also for books on topics such as mental healing in which Fryer himself took an interest. ${ }^{66}$

From 1886 he also ran a Chinese Prize Essay Contest, intended to stimulate writing about 'useful knowledge' rather than the stultified and artificial essays which the literary examinations demanded. The topics were set by Chinese officials, and prize-winners, in addition to a small cash prize, had their essays bound and published. The subjects set ranged across issues of naval defence, tea and silk production, whether Chinese or Western languages should be used to teach 'Western studies', the translation of chemical terms, railways, steamships and telegraphy, opium-smoking, Western and Chinese legal sanctions, and the differences between Western and Chinese science ${ }^{67}$ Fryer was delighted with what

63 Fryer, op. cit. (60), 44.

64 John Fryer to the [unnamed] Head of the Unitarians, n.d., probably 1885, FP: Box 1 Folder 6.

65 Li San-po, 'Letters to the Editor in John Fryer's Scientific Magazine', Bulletin of the Institute of Modern History, Taibei (1974), 4, 729-77. For the contemporary state of British science journals, see W. H. Brock, 'The development of commercial science journals in Victorian Britain', in Development of Science Publishing in Europe (ed. A. J. Meadows), Amsterdam, 1980, 95-122.

66 See Fryer's report on the Depot in North China Herald, 28 December 1897, 702-3.

67 The essays are collected in Wang Tao (ed.), Gezhikeyi huibian, Shanghai, 1897, and reports on the essays may be found in the North China Herald, 25 January 1888, 100-1; 20 July 1889, 85-6; 1 November 1889, 536-7; and 14 April 1893,513-14. The essays are a rich source of information on how contemporary Chinese observers saw the influx of Western ideas, technology and science, and contain, amongst other things, some of the earliest references in Chinese to Charles Darwin (e.g. ibid. 4.1a, 4.6a, 4.9b, 4.16a and 5.42b). The very earliest Darwin 
he saw as the demonstration of an 'astonishing amount of general knowledge compared with what might have been expected' ${ }^{68}$ Although the essayists said little that was original, the fact that they paid attention to such subjects demonstrated some acceptance of the need to study Western knowledge, and provided a marked contrast with the literary emphasis which still dominated the official examinations.

\section{'ALIVE WITH BUSY WORKERS': THE POLYTECHNIC IN ITS HEYDAY}

From 1885 new rules for the Polytechnic were drafted, stipulating that the Curator should be

a trustworthy native possessed of a reasonable amount of Western knowledge... He shall live entirely on the premises and take charge of them, night and day, giving his whole time and attention to the books and apparatus, to entertaining or answering the questions of visitors and enquirers and to promoting and advancing the purposes for which the Institution was founded. ${ }^{69}$

The foreign members of the Management Committee now took a more active role in the running of affairs, and to prevent a repetition of past problems, the Curator's family were no longer allowed to live on the premises. From the same year, the scholarly journalist Wang Tao (1828-97) became shanzhang, and it was under his guidance that the Prize Essay scheme on topics relevant to the sciences and practical progress flourished. It seems that around this time some elementary science classes began to operate. In 1886 there was a proposal that a foreign professor be appointed, and after a four-year delay a Western scientist called Cosmo Innes Burton was employed to begin lectures: he set about enthusiastically preparing his courses in mining, metallurgy and mineralogy, but unfortunately died before he could begin teaching. ${ }^{70}$

It was not until 1895, over twenty years after the foundation of the Polytechnic, that regular free classes were run on Saturday evenings by Fryer and his son John Rogers Fryer (1872-96), others by a Chinese lecturer Lu Rentang. Starting at 4 p.m., afternoon preparatory classes in arithmetic and algebra were held with berween fifteen and thirty students, and higher classes were held from 7 to 8 p.m., as the students were found to be weak in these aspects. ${ }^{71}$ Examinations, strictly invigilated by Fryer himself, were held with a 75 per cent pass mark, and certificates were issued to successful candidates. Fryer described the classes themselves:

From four o'clock on Saturday afternoon when the beginners receive their lessons up to half-past eight when the advanced class is dismissed and the magic lantern lectures commence, the

reference, in another Chinese journal, is as 'Dayun' in Shen Bao (21 August 1873), 2 and again as 'Duierping' in Dixue qianshi, Shanghai, 1873, 13.16a, the latter being a Jiangnan Arsenal translation of Lyell's Elements of Geology (6th edn) by Hua Hengfang and Daniel Jerome Macgowan (1814-93). There is also a brief account of the Darwinian theory in an anonymous article (possibly by Fryer himself), enigmatically entitled 'Huntun shuo' [On chaos] in Gezhi Huibian (1877), 2, 6a-7a. See also James Reeves Pusey, China and Charles Darwin, Cambridge, MA, 1983.

68 Bennett, op. cit. (39), 58.

69 Fryer, op. cit. $(60), 45$.

70 North China Herald, 15 August 1890, 196; Gezhi Huibian (1890), 5, 45a-46b and ibid. (1890), 5, 43a-43b.

71 North China Herald, 16 July 1897, 128. 
building is alive with busy workers, and there is a continuous succession of visitors or enquirers coming and going, who are allowed to sit on the side seats and see what is going on. Seats and tables or desks are arranged for forty students, but next year more must be added. The magic lantern lectures are open to the students and their friends. They were commenced early in the autumn [of 1895]. During the Chinese year the following subjects have been treated, most of them with two subjects each: 'Mines and mining operations'; 'Lady Brassey's tour round the world in the Sunbeam'; 'Physiology and Anatomy'; 'The viceroy's new road and other objects of interest at Nanking'; 'The Chicago Exposition'; and 'Zoology'. These six subjects were enlivened by various other smaller sets of lantern slides of an amusing or instructing character. It is proposed next year to take up the various departments of Natural Philosophy one by one and to illustrate them in the same manner. Many questions are asked by the audience as the lectures proceed, and as this adds much to their interest such questions are encouraged. ${ }^{72}$

\section{'CHEWING WAX': CHEMISTRY CLASSES IN THE SHANGHAI POLYTECHNIC}

We are fortunate in also having a first-hand Chinese account of the teaching of the chemistry classes by a volunteer demonstrator, Luan Xueqian $:^{73}$

Now I myself knew a little [chemistry] and had some friends who had graduated from the Shanghai Polytechnic, so I was not afraid of being too ignorant, and since the recent opening of the Polytechnic every Saturday evening we went through a few sections of Huaxue jianyuan [The mirror of chemistry: a source-book]. ${ }^{74}$ The first few chapters of that book are about the laws of chemistry and its principles are very profound : for the audience it had the flavour of chewing wax. For in learning chemistry it is not possible to skip over these matters: you have to explain it gradually ... From this time we began studying oxygen in the second chapter and then continued with hydrogen. All this was about real substances and real things [shizhi shishi], and was therefore easier for students to understand. After this we did three experiments, the first being on oxygen, for which we used potassium chlorate and manganese dioxide, which we ground to a powder and put in a copper pot... and heated, obtaining oxygen. ${ }^{75}$

Luan then described seeing the effect of oxygen on the burning of a candle, and the attempted combustion of sulphur and steel wire in oxygen. They also made hydrogen and carried out a hazardous experiment in which bubbles of hydrogen and oxygen gases were made to explode. Luan continued:

Thus I and Lu Rentang attempted to do the experiments ourselves [in order to] satisfy the minds of the students, even though [we were] only novices, and were unable to do them all. The apparatus the Polytechnic had was damaged and incomplete, [some of it] could not be used and needed to be replaced, so in two hours it was hard to do everything, it was not that we begrudged doing the experiments. Since we did not try to hide our inadequacies by keeping quiet, the students forgave us. From this time on, we taught about the principles of nitrogen and chlorine, up until the 10th day of the sixth lunar month, then having a holiday of one month. The Polytechnic reopened on the tenth day of the seventh lunar month, and until the seventeenth day

72 North China Herald, 21 February 1896, 287.

73 Luan Xueqian collaborated with Fryer on Huaxue weisheng lun [On chemistry and health], a translation of J. W. Johnston, The Chemistry of Common Life, published between 1876 and 1881 in Gezhi Huibian. Luan Xueqian also ran the Chinese Scientific Book Depor after Fryer left China.

74 This text had been translated from David Wells, Principles and Applications of Chemistry, New York, 1862, by John Fryer and Xu Shou and published by the Jiangnan Arsenal in 1871.

75 Luan Xueqian, 'Gezhi shuyuan jiaoyan huaxue ji' [A note on the teaching of chemistry at the Shanghai Polytechnic], Kexue [Science] (1924), 8, 430-2. 
we performed experiments on nitrogen. Afterwards we continued to teach and perform experiments term by term.

The difficulties of the students studying chemistry with the textbooks then available were enormous. Unfamiliar vocabulary, and grossly inadequate explanations of fundamental theory, made it a task with which only the most dedicated would persevere. Yet the Polytechnic classes clearly attracted a number of eager students, of whom some at least went on to more serious studies.

\section{CONCLUSION: THE BREAKING OF THE WALL}

Why had the 'empty halls' of the 1877 academy become 'alive with busy workers' by 1896 ? The setbacks the Chinese had suffered at the hands of European nations since 1840 were humiliating enough, but for the Celestial Empire to be defeated by the Japanese in the war of 1894-95 was a shocking demonstration of China's weakness. Japan's willingness to modernize was generally accepted as the reason for its new military strength, and this generated amongst a portion of the Chinese intellectuals a new respect for Western Studies, a change of heart which would eventually sweep away the traditional literary examinations and introduce natural science as part of a new educational curriculum. ${ }^{76}$ The writings of reform-minded intellectuals also began to show the influence of science translations, and it is significant that of the reformers it was Tan Sitong (1865-98) - on whom Western science had the deepest influence - who was also the most iconoclastic. ${ }^{77}$

After leaving China, Fryer wrote:

The walls of obstruction are gradually being broken down by the spread of Western learning. A strong demand has set in among the thinking part of the nation for all the useful knowledge foreigners have to impart. $^{78}$

Despite this apparent optimism, in 1896 he accepted an offer of a professorship in Oriental Languages in the University of California at Berkeley. The Polytechnic continued after Fryer's departure for the USA, but the halcyon days of 1894-97 never returned. After the Boxer Rebellion in 1900, as government schools with science curricula were set up, and Chinese students in increasing numbers went abroad - particularly to Japan - to study science, the Polytechnic lost its unique position, although up until 1901 it still held the only Chinese library in Shanghai. ${ }^{79}$ By 1904 the science classes had ceased, and in 1917 a school (now known as the Shanghai Science Middle School) was built on the site.

John Fryer's Shanghai Polytechnic therefore provided spaces for Western science where it could - however imperfectly - be transmitted. This and similar institutions generated channels which in the following decades both deeply undermined the traditional view of

76 Mathematics questions had been allowed by an imperial edict in 1887. See W. T. A. Barber, 'A Chinese examination paper', North China Herald, 7 July 1888, 15.

77 See Chan Sin-wai, An Exposition of Benevolence: The Jen-hsueh of T'an Ssu-t'ung, Hong Kong, 1984, and David Wright, 'Tan Sitong and the ether reconsidered', Bulletin of the School of Oriental and African Studies, London University (1994), 57, 551-75.

78 John Fryer, 'The commerce of China', 22 October 1898, FP: Carton 1, 29.

79 Hu Daojing, 'Shanghai tushuguanshi' [A history of Shanghai libraries] in Shanghai Shi Tongzhiguan Qikan (1935), 4, 1356-7. 
the natural world, and also promoted science as a source of enlightenment and progress, a powerful ally against the forces of feudal superstition and ignorance. During the May Fourth Movement of 1919, 'Science and Democracy' became the slogan of the patriotic students, and it is clear that by 'science' they meant both its intellectual achievements and the scientific outlook itself, which seemed to them to encourage their challenge to ancient orthodoxies. The political dimensions of modern science, in its appeal to external criteria of validity, have since reappeared in the debates about the nature of truth and dogmatism which followed the death of Mao Zedong ${ }^{80}$ and again in the student protests of $1989 .{ }^{81}$ Science in China is still able to create new spaces and undermine old walls.

\section{GLOSSARY OF CHINESE TERMS}

I have included here all personal names, terms, and premodern book-titles, but not titles of works in modern Chinese, as the latter may be readily reconstructed from the romanized form.

Bowu xinbian 博物新编

Chen Yuanhui 陈元挥

Dayun 大䓝

dao 道

Dixue qianshi 地学浅释

Duierping 总儿平

Fang Lizhi 方矿之

geyi 格义

gezhi 格致

Gezhi Huibian 格致汇编

Gezhi keyi huibian 格致课艺汇编

Gezhi Shushi 格致抢室

Gezhi Shuyuan 格致书院

$\mathrm{Hu}$ Daojing 胡道静

Hua Hengfang 华蘅芳

Huaxue jianyuan 化学鉴原

Huaxue weisheng lun 化学卫生论

Huntun shuo 混沌说

kaozheng 考证

li 理

Li Hongzhang 李鸿章

Li Shanlan 李善兰

Liu Xihong 刘锡鸿

Lu Rentang 陆仁堂

Luan Xueqian 集学谦 mufu 幕府

qi 气

shanzhang 山长

Shen Bao 申报

Shanghai Xinbao 上海新报

shizhi shishi 实质实事

shy 数

shuyuan 书院

Tan Sitong 谭嗣同

Tongwenguan 同文馆

Wang Ermin 王尔敏

Wang Tao 王韬

Wuxi 无锡

Xiong Yuezhi 熊月之

$\mathrm{Xu}$ Jianyin 徐建寅

Xu Shou 徐寿

Xu Zhonghu 徐仲虎 yangwu yundong 洋物运动

yi lin zhi tang 艺林之堂

yin-yang 阴阳

Yingyao siji 英轺私记

Zeng Guofan 曾国藩

Zheng Guanying 郑观应

Zhong Shuhe 钟叔河

80 'Shijian shi jianyan zhenli de weiyi biaozhun' [Practice is the sole criterion of truth], Guangming Ribao, 11 May 1978, 1.

81 Fang Lizhi, Bringing Down the Great Wall: Writings on Science, Culture, and Democracy in China, New York, 1990. 